\title{
Technical and economic viability of Eucalyptus sp. coppice for charcoal production
}

\author{
Clarissa Gusmão Figueiró ${ }^{1}$, Angélica de Cássia Oliveira Carneiro' ${ }^{1}$, Lucas de Freitas Fialho' ${ }^{1}$,

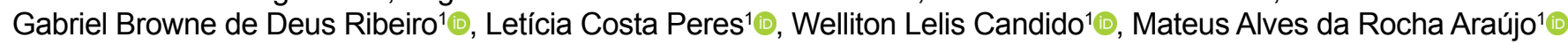 \\ 1 Universidade Federal de Viçosa, Viçosa, MG, Brasil. E-mail: clarissagfigueiro@gmail.com; cassiacarneiro1@gmail.com; l.freitasfialho@gmail.com; gabrielbrowne@gmail.com;
leticiacostaperes@gmail.com; welliton.florest@gmail.com; mateus.a.araujo@ufv.br
}

ABSTRACT: The aim of this study was to compare the properties of wood and charcoal of Eucalyptus sp., from two silvicultural systems (replanting and coppicing), in addition to assessing the economic viability of both systems, through the financial indicators Net Present Value (NPV), Internal Rate of Return (IRR) and Payback. The study was carried out in a charcoal producing company, located in the municipality of Itamarandiba, Minas Gerais, Brazil. The results showed that the wood from the coppice system has a lower Mean Annual Increment and a higher heartwood/sapwood ratio, producing a more friable charcoal and with lower productivity compared to the replanting system. Regarding the economic analysis, both systems were economically viable, with an IRR greater than the discount rate and a positive NPV. Comparatively, the economic results of the coppice system were slightly better, presenting less vulnerability in the sensitivity analysis regarding fluctuations in the price of charcoal. The option for coppice may be interesting for the producer due to its lower financial expenditure and satisfactory economic results, although with lower product quality.

Key words: friability; heartwood/sapwood ratio; internal rate of return; net present value; regrowth

\section{Viabilidade técnica e econômica da talhadia de Eucalyptus sp. para a produção de carvão vegetal}

RESUMO: O objetivo deste estudo foi comparar as propriedades da madeira e do carvão vegetal de Eucalyptus sp., provenientes de dois sistemas silviculturais (replantio e talhadia), além de avaliar a viabilidade econômica de ambos os sistemas, por meio dos indicadores financeiros Valor Presente Líquido (VPL), Taxa Interna de Retorno (TIR) e Payback. $O$ estudo foi realizado em uma empresa produtora de carvão vegetal, localizada no município de Itamarandiba, Minas Gerais, Brasil. Os resultados demonstraram que as madeiras provenientes do sistema de talhadia apresentaram menor incremento médio anual e maior relação cerne/alburno, produzindo um carvão mais friável e com menor produtividade em comparação ao sistema replantio. Em relação à análise econômica, ambos os sistemas foram viáveis economicamente, com TIR maior que a taxa de desconto e VPL positivo. Comparativamente, os resultados econômicos do sistema de talhadia foram um pouco melhores, apresentando menor vulnerabilidade na análise de sensibilidade quanto a flutuações do preço de carvão. A opção pela talhadia pode ser interessante para o produtor em função de seu menor dispêndio financeiro e dos resultados econômicos satisfatórios, embora com menor qualidade do produto madeireiro.

Palavras-chave: friabilidade, relação cerne/alburno; taxa interna de retorno; valor presente líquido; rebrota 


\section{Introduction}

The forest-based activities in Brazil are fundamental for economic, social and environmental development (Ribeiro et al., 2018). In 2018, the reforestation area for industrial purposes was 7.83 million hectares, with products from these forests accounting for $6.9 \%$ of the country's industrial GDP. Such activities provided a large volume of jobs that directly and indirectly benefited approximately 3.8 million people (IBÁ, 2019). In addition, from an environmental point of view, forest production contributes to reducing pressure on native forests and their predatory exploitation, which helps to conserve the biodiversity of these ecosystems.

Eucalyptus is the main genus used to supply the Brazilian forestry sector, being this genus the most used to produce pulp and paper, charcoal and solid wood products. The rapid growth, the ability to adapt to different edafloclimatic conditions and high productivity, optimized by the constant development of silvicultural techniques and genetic improvement, justify its wide use (Carneiro et al., 2013). Another interesting advantage of eucalypts is its ability to emit shoots after being harvested. Such shoots can be conducted to form a new individual, using a set of silvicultural techniques called coppicing, which therefore dispenses the need to replant (Xavier et al., 2009).

Since the first plantations of the Eucalyptus genus in Brazil, the management of shoots in the second rotation of forests is a reality in the management of this culture. Although, in most cases, the implementation of this system causes a decrease in the productivity of the forest, this disadvantage can be minimized with the reduction of the expenses with replanting the area. In addition, since interventions in the environment are reduced, the negative impact of this activity on the soil is reduced (Cacau et al., 2008; Gonçalves et al., 2014). However, the effect of coppicing on the quality of the final wood product, such as charcoal, is still little studied.

Charcoal is a product obtained through the carbonization of wood. In this thermochemical conversion process, the wood is subjected to low heating rates, in a controlled oxygen atmosphere, with final temperatures varying between 300 to $500{ }^{\circ} \mathrm{C}$. The product of greatest interest obtained in this process is charcoal, a solid material with a high concentration of carbon (Mohan et al., 2006; Pereira et al., 2013). In addition to the process variables, such as final carbonization temperature, heating and cooling rate, the quality of the charcoal is highly influenced by the quality of the wood (Chen et al., 2015; Figueiró et al., 2019; Ucar \& Ozkan., 2008).

In order to compare replanting and coppicing systems, it is necessary to analyze the quality of the wood and the final product generated in both systems, as well as to evaluate the economic viability of these systems, in view of the lower financial expenditure that usually occurs in the coppicing system - because it is a system with reduced interventions. Thus, it is necessary to carry out an economic evaluation of these forest projects, together with a sensitivity analysis of the main risk variables (Oliveira et al., 2014; Ribeiro et al., 2020). From these analyzes, forest producers will be able to make a more efficient decision-making on whether or not to carry out this silvicultural procedure.

Thus, the aim of this study was to compare the properties of wood (heartwood/sapwood ratio, basic density, chemical composition, higher heating value) and charcoal (gravimetric yield, apparent density, friability, proximate analysis, higher heating value), from two silvicultural systems (replanting and coppicing), in addition to assessing the economic viability of both systems.

\section{Materials and Methods}

\section{General characterization of the study area}

The study was carried out in a charcoal producing company located in the municipality of Itamarandiba, Minas Gerais, Brazil. The wood and charcoal properties of a clone, hybrid of Eucalyptus grandis W. Hill ex Maiden x Eucalyptus urophylla S.T.Blake, at 7 years of age, from commercial plantations with 3 x $3 \mathrm{~m}$ spacing, that were subjected to two types of silvicultural practices, replanting and coppicing, were evaluated.

The soil where the plantations were located is characterized as dystrophic red latosol and typical dystrophic red-yellow latosol, with a clayey or very clayey texture, the topography being considered flat (plateau) (Pulrolnik et al., 2009; Henriques, 2012). The edaphoclimatic condition is of annual rainfall of 1000 to $1200 \mathrm{~mm}$, average temperature of 20 to $22{ }^{\circ} \mathrm{C}$, and the climate is classified as Cwa according to Koppen's classification, dry-winter humid subtropical climate (Alvares et al., 2013).

\section{Data collection and analysis}

To characterize wood and charcoal, from replanting and coppicing systems, the mean annual increment of trees, in addition to the properties of wood and charcoal, were analyzed. The wood variables determined were: heartwood/ sapwood ratio, basic density, chemical composition and higher heating value. For charcoal, in addition to gravimetric yield, the following properties were determined: apparent density, friability, proximate analysis, higher heating value.

For this, five trees from a coppice management and five trees from replanting, of average population diameter, were used, totaling ten trees. Those individuals who had visual defects and/or located on the borders of the area were discarded.

The volume of the trees was obtained from measurements of the diameter along the stem, from the cutting base to the minimum diameter of $7 \mathrm{~cm}$. The formula proposed by Smalian was used, where the volume of each section of the tree was estimated, for later obtaining the total volume (Ribeiro et al., 2017). Then the average volume of trees harvested was multiplied by the number of trees per hectare. Thus, by dividing the volume of wood per hectare $\left(\mathrm{m}^{3} \mathrm{ha}^{-1}\right)$ by age (years), the mean annual increment (MAl) was obtained.

The determination of the heartwood/sapwood ratio was performed with the aid of a magnifying glass with a tenfold magnification, in which the transition region between 
heartwood and sapwood was identified. The total sapwood area was obtained, and by difference, in relation to the total disc area, the heartwood area was calculated.

The basic density of the wood was determined according to the water immersion method described by the standard ABNT NBR 11941 (ABNT, 2003).

The total extractives content was determined according to TAPPI 204 om-88 (TAPPI, 2001). The determination of soluble and insoluble lignin was carried out according to Gomide \& Demuner (1986) and Goldschmid (1971), respectively. The total lignin content was obtained by adding the contents of insoluble lignin and soluble lignin. The ash content was determined according to the standard ABNT NBR 8112 (ABNT, 1986). The holocellulose content was calculated by subtracting the total lignin, extractive and ash contents from 100.

An IKA300 adiabatic calorimetric pump was used, according to the methodology described by ABNT NBR 8633 (ABNT, 1984), for the evaluation of the higher heating value of wood.

The carbonization of the wood was carried out in an electric muffle furnace, using $400 \mathrm{~g}$ of oven-dried wood, at $103 \pm 2{ }^{\circ} \mathrm{C}$. The samples were inserted in a $0.003 \mathrm{~m}^{3}$ metal container, located inside the muffle furnace. The temperature control was performed manually, in increments of $50^{\circ} \mathrm{C}$ every 30 minutes, corresponding to a heating rate of $1.67^{\circ} \mathrm{C} \mathrm{min}^{-1}$, until the final temperature of $450{ }^{\circ} \mathrm{C}$, remaining stabilized in the latter by 60 minutes. After the end of carbonization, the gravimetric yield in charcoal was determined by gravimetry.

The apparent density of charcoal was determined according to Figueiredo et al. (2018). The charcoal friability was evaluated using a friabilometer, samples with known mass were rotated for 17 minutes at $35 \mathrm{rpm}$, weighed, and the percentage of mass loss calculated.

The volatile matter and ash contents in charcoal were determined according to ABNT NBR 8112 (ABNT, 1986). The fixed carbon content was calculated by subtracting the contents of volatile matter and ash from 100 . The higher heating value was determined using an IKA300 adiabatic calorimetric pump, according to the methodology described by ABNT NBR 8633 (ABNT, 1984).

The data for the wood and charcoal variables, from the coppice and replanting systems, were subjected to the Lilliefors test for normality, and the Cochran test for homogeneity of variances. Subsequently, the results were subjected to analysis of variance ( $F$ test, $p<0.05$ ). For this, the statistical analysis software R (R Core Team, 2018) was used.

\section{Economic evaluation of forest projects}

To develop a comparative economic analysis between forestry projects, these were called projects A - replanting and B - coppicing. The Discounted Cash Flow (DCF) method was used, considering a 21-year planning horizon for each project. Thus, two complete rotations of the regulated plantations were considered, in order to guarantee an annual flow of wood. In the regulated forests, a stand is implanted each year and from the moment the first stand is at the harvesting point, a stand is harvested each year (Silva \& Ribeiro, 2006).
The total area considered for each of the projects was 60.69 hectares. To facilitate calculations of wood production, revenues and costs, the total area was divided into seven areas of identical size, resulting in 8.67 hectares to be implanted and, later, harvested per year. Thus, to work with a regulated forest, from the year 7 of the project and until the year 20, every year there will be a harvested area of $8.67 \mathrm{ha}$.

In the DCF methodology, the value of the project is measured by the amount of financial resources that will be generated in the future by the business, which is brought to present value to reflect the time and risk associated with the distribution (Martelanc et al., 2010). In this way, cash flow is projected from inflows (revenues) and outflows (costs).

The only financial input from the projects is the revenue from the sale of charcoal, which begins in year 7 , with the production of the first area, its harvest and production of charcoal; and ends in year 20, with the harvest and production of charcoal from last area. The selling price of charcoal of $\mathrm{R} \$ 600.00$ ton $^{-1}$ was considered, which is the average price practiced in the region, according to company data.

Outputs (costs) were divided into forest costs and financial costs. For project A (replanting) the forest costs were: planting implementation costs; maintenance; harvest and removal of the tree stumps; and carbonization cost (Table 1). For project $B$ (coppicing), maintenance costs were the same, but implementation and harvesting costs were lower because they had fewer necessary activities (Table 2). All data were obtained from the forestry company.

The production cost of charcoal (carbonization) was obtained from the company, being estimated as a fixed cost of R\$ 85.17 per ton of charcoal produced, including labor, machinery, and fuel necessary for the complete operation of carbonization. The costs of building the kilns were not included in these projects, since the company already has them.

The estimated financial costs were: economic cost of land; financial expenses with financing (which was simulated for each project), taxation and depreciation of the investment. The economic cost of land was calculated according to Silva et al. (2008), considering the project's interest rate of $10.00 \%$ per year and the land value in the region of $R \$ 4,000.00$ hectare $^{-1}$ (Emater, 2019).

A financing with the Brazilian Development Bank (BNDES) of $R \$ 117,223.70$ was simulated, the same amount for each project. This financing refers to the total amount of forest implantation (investment expenses) for all 60.69 hectares (that is, $\mathrm{R} \$ 1,931.40$ hectare $^{-1}$ implanted times the total amount of hectares of the project). These silvicultural expenses can be financed by the BNDES' Pronaf ECO financing line. The simulated conditions were: term of 10 years, grace period of 7 years, final financing rate of $4.60 \%$ per year and monthly payment periodicity via CAS - Constant Amortization System.

Taxation was considered to be $9.76 \%$ of the profit. This value was obtained in Imaña et al. (2015) for a forestry company producing charcoal in the state of Minas Gerais. This amount can be considered reduced since the state exempts charcoal producers from charging ICMS. An investment 
Table 1. Forest costs for planting/replanting.

\begin{tabular}{|c|c|c|c|c|c|}
\hline Costs - Planting / Replanting & Year & Unit & Amount & $\begin{array}{c}\text { Value } \\
\text { R\$ Unit }{ }^{-1}\end{array}$ & $\begin{array}{c}\text { Cost } \\
R \$ h^{-1}\end{array}$ \\
\hline Soil preparation & 1 & $\mathrm{~h} \mathrm{ha}^{-1}$ & 4.00 & 80.00 & 320.00 \\
\hline Subsoiling & 1 & h ha-1 & 1.00 & 60.00 & 60.00 \\
\hline Gypsum & 1 & kg ha-1 & 500.00 & 0.04 & 20.00 \\
\hline Chemical fertilizer & 1 & $\mathrm{~kg} \mathrm{ha}^{-1}$ & 250.00 & 1.00 & 250.00 \\
\hline Herbicide & 1 & L ha-1 & 5.00 & 18.00 & 90.00 \\
\hline Fertilizing & 1 & h ha-1 & 5.00 & 30.00 & 150.00 \\
\hline Seedlings & 1 & un ha-1 & $1,666.00$ & 0.40 & 666.40 \\
\hline Planting & 1 & h ha-1 & 6.50 & 30.00 & 195.00 \\
\hline Ant control & 1 & h ha-1 & 6.00 & 30.00 & 180.00 \\
\hline Total cost of implementation & & & & & $1,931.40$ \\
\hline Ant control & 2 & $\mathrm{~h} \mathrm{ha}^{-1}$ & 6.00 & 30.00 & 180.00 \\
\hline Manual weeding & 2 & h ha-1 & 5.00 & 30.00 & 150.00 \\
\hline Manual weeding & 3 & h ha-1 & 5.00 & 30.00 & 150.00 \\
\hline Administration and maintenance & $1-7$ & - & 7.00 & 11.00 & 77.00 \\
\hline Total cost of maintenance & & & & & 557.00 \\
\hline Harvest & 7 & $\mathrm{~m}^{3}$ & 237.36 & 12.00 & $2,848.27$ \\
\hline Chemical stump removal & & h ha-1 & 5.00 & 30.00 & 150.00 \\
\hline Total harvest + stump removal cost & - & - & - & - & $2,998.27$ \\
\hline Total cost per hectare & & & & & $5,486.67$ \\
\hline
\end{tabular}

Table 2. Coppicing system costs.

\begin{tabular}{|c|c|c|c|c|c|}
\hline Costs - Conduction & Year & Unit & Amount & Value $\mathrm{R} \$$ Unit $^{-1}$ & Cost R\$ ha-1 \\
\hline Thinning & 1 & h ha-1 & 5.00 & 30.00 & 150.00 \\
\hline Ant control & 1 & $\mathrm{~h} h \mathrm{a}^{-1}$ & 6.00 & 30.00 & 180.00 \\
\hline Total cost of implementation & & & & & 330.00 \\
\hline Ant control & 2 & h ha-1 & 6.00 & 30.00 & 180.00 \\
\hline Manual weeding & 2 & h ha-1 & 5.00 & 30.00 & 150.00 \\
\hline Manual weeding & 3 & h ha-1 & 5.00 & 30.00 & 150.00 \\
\hline Administration and maintenance & $1-7$ & - & 7.00 & 11.00 & 77.00 \\
\hline Total cost of maintenance & & & & & 557.00 \\
\hline Harvest & 7 & $\mathrm{~m}^{3}$ & 165.58 & 12.00 & $1,986.97$ \\
\hline Total cost per hectare & & & & & $2,873.97$ \\
\hline
\end{tabular}

depreciation rate of $10 \%$ per year was also considered. In addition, the project's discount rate (cost of capital) was set at $10 \%$ per year, which is common for silvicultural projects.

The financial indicators used to analyze the economic viability of the projects were the Net Present Value (NPV), the Internal Rate of Return (IRR) and the Payback indicator. NPV (Equation 1) is the formula used to determine the present value of future payments discounted at a certain interest rate, less the cost of the initial investment.

$$
N P V=\sum_{j=0}^{n} R j(1+i)^{-j}-\sum_{j=0}^{n} C j(1+i)^{-j}
$$

where: $\mathrm{i}=$ interest rate; $\mathbf{C j}=$ cost at the end of the year $\mathrm{j} ; \mathrm{Rj}$ $=$ revenue at the end of the year $\mathrm{j} ; \mathrm{e}, \mathrm{n}=$ project duration in years.

The IRR (Equation 2) is the discount rate that equals the present value of revenues to the present value of costs, that is, it equals NPV to zero (Martelanc et al., 2010).

$$
\sum_{j=0}^{n} R j(1+I R R)^{-j}=\sum_{j=0}^{n} C j(1+I R R)^{-j}
$$

where: $\mathrm{Cj}=$ cost at the end of the year $\mathrm{j} ; \mathrm{Rj}=$ revenue at the end of the year $\mathrm{j} ; \mathrm{e}, \mathrm{n}=$ project duration in years.

The Payback indicator is used to determine how long an investment takes to be repaid. Its calculation is done by accumulating the inflows and outflows, and determining the period in which there was a transition from a negative to a positive value, that is, the moment when everything that was invested is recovered (Martelanc et al., 2010).

\section{Results and Discussion}

\section{Characterization of wood and charcoal}

The heartwood/sapwood ratio and extractives content of the wood, in addition to friability and productivity in charcoal, showed significant differences between replanting and coppicing systems (Table 3 ).

The heartwood/sapwood ratio was higher in wood from the coppicing system, compared to wood from replanting. In species subjected to coppicing, a slower growth rate occurs, which in turn is accompanied by greater cell wall thickening, accumulation of extracts and cell inactivity, phenomena that characterize the heartwood formation (Kumar \& Dhillon, 2014; Cherelli, 2015; Trugilho et al., 2019). 
Table 3. Properties of wood and charcoal.

\begin{tabular}{|c|c|c|c|}
\hline \multirow{2}{*}{ Properties } & \multicolumn{2}{|c|}{ System } & \multirow{2}{*}{-Probability } \\
\hline & Replanting & Coppicing & \\
\hline \multicolumn{4}{|l|}{ Wood } \\
\hline Mean annual increment $\left(\mathrm{m}^{3} \mathrm{ha}^{-1}\right.$ year $\left.{ }^{-1}\right)$ & 34.60 & 26.88 & $0.045^{*}$ \\
\hline Heartwood / sapwood ratio (\%) & 0.66 & 0.89 & $0.020 *$ \\
\hline Basic density $\left(\mathrm{kg} \mathrm{m}^{-3}\right)$ & 555.79 & 535.69 & 8.804 \\
\hline Extractive content (\%) & 3.47 & 6.54 & $0.046^{*}$ \\
\hline Lignin content (\%) & 30.04 & 29.06 & 25.577 \\
\hline Holocellulosis content (\%) & 66.49 & 64.40 & 0.709 \\
\hline Higher heating value $\left(\mathrm{MJ} \mathrm{kg}^{-3}\right)$ & 19.13 & 19.33 & 1.766 \\
\hline \multicolumn{4}{|l|}{ Charcoal } \\
\hline Gravimetric yield (\%) & 34.67 & 34.59 & 14.866 \\
\hline Apparent density $\left(\mathrm{kg} \mathrm{m}^{-3}\right)$ & 341.85 & 372.73 & 1.851 \\
\hline Friability (\%) & 8.38 & 9.68 & $0.014^{*}$ \\
\hline Volatile matter content (\%) & 26.33 & 26.57 & 265.999 \\
\hline Ash content (\%) & 0.35 & 0.32 & 0.320 \\
\hline Fixed carbon content (\%) & 73.32 & 73.11 & 169.595 \\
\hline Higher heating value $\left(\mathrm{MJ} \mathrm{kg}^{-3}\right)$ & 30.14 & 31.12 & 16.602 \\
\hline
\end{tabular}

Legend: * Significant at 5\% probability, by $\mathrm{F}$ test.

Thus, when the objective is the production of charcoal, a greater heartwood/sapwood ratio influences the wood drying process, either in the field or during carbonization. The heartwood, due to its low permeability, can hinder the release of water vapor during the drying of the wood, which can cause ruptures in parenchymal cells, resulting in a more friable charcoal (Costa et al., 2016). Thus, a greater heartwood/ sapwood ratio, as observed in wood from the coppicing system, causes an increase in the friability of charcoal.

The extractives content is related to the heartwood formation process. Thus, woods that have a higher proportion of heartwood, such as those from the coppicing system, have a higher extractive content. The influence of extractives on the quality of charcoal will depend on the chemical nature of these components. Extractives of phenolic origin, for example, can contribute to the increase in the calorific value of wood and charcoal, in addition to the gravimetric yield in charcoal (Frederico, 2009).

The friability of charcoal refers to the tendency of this material to form fines when subjected to abrasive forces and mechanical shocks. The fines content is characterized as the residual fraction of charcoal, which although it can be used as supplementary fuel in the blast furnace, has as a consequence economic losses in the production of the product of greater added value, charcoal (Cardoso, 2010 ). The greater friability of the charcoal in the wood from the coppicing system, as well as the extractive content, is attributed to the greater heartwood/sapwood ratio presented in the wood from this silvicultural system.
The lignin content of the wood did not show any significant difference between materials from the coppice and replanting. Lignin has a high resistance to thermal degradation, due to the presence of a greater number of $C-C$ and $C=C$ bonds in its structure, in addition to having a high percentage of elemental carbon and low oxygen content, when compared to holocelluloses (Haykiri-Acma et al., 2010). Therefore, this property is directly correlated with the higher heating value of the wood, in addition to the gravimetric yield, proximate analysis and higher heating value of the charcoal (Carneiro et al., 2017), which justifies not observing significant differences for these properties.

\section{Wood and charcoal production}

The mean annual increment in the coppicing system, compared to the replanting system, showed lower values (Table 4). This reduction may be related, mainly, to the number of shoots conducted by stem and the reduction of vegetative vigor. Plants originating from shoots have a lower vegetative vigor than plants originating from replanting, which can compromise the growth and development of the tree (Stape et al., 2010).

The evaluation of the mean annual increment (MAI) is essential in forestry projects, as in the case of the charcoal sector, since lower values of MAl, are associated with the production of a lower volume of wood per hectare, in a given period, which affects the profitability of the activity.

From the productivity of $34.60 \mathrm{~m}^{3} \mathrm{ha}^{-1} \mathrm{year}^{-1}$, the cutting cycle of 7 years and the mortality rate of $2.00 \%$, production in 7 years reached $2,058.00 \mathrm{~m}^{3}$ to 8.67 ha. This volume of wood was obtained for the 1st cycle of projects $A$ and $B$, and for the second cycle of project $A$ (replanting). In project $B$, the coppicing system led to lower productivity in the 2 nd cycle, of $26.88 \mathrm{~m}^{3} \mathrm{ha}^{-1}$ year ${ }^{-1}$, with a mortality rate of $12.00 \%$, resulting in $1,435.67 \mathrm{~m}^{3}$ of wood production.

Charcoal productivity is the result of the interaction between wood production and its gravimetric yield. Therefore, when analyzing wood from the coppicing system, despite showing the same gravimetric yield as those from replanting, it presented materials with lower MAI and greater friability of charcoal, which justifies this decrease in productivity $\left(t \mathrm{ha}^{-1}\right)$ of charcoal.

Evaluating the production of charcoal, given the capacity of the kiln of $140 \mathrm{~m}^{3}$ of wood, it is possible to carry out 14

Table 4. Wood and charcoal production.

\begin{tabular}{|c|c|c|c|}
\hline Production data & Unit & Replanting & Coppicing \\
\hline Mean annual increment & $\mathrm{m}^{3} \mathrm{ha}^{-1}$ year $^{-1}$ & 34.60 & 26.88 \\
\hline Wood volume & $\mathrm{m}^{3}$ area $^{-1}$ & $2,058.00$ & $2,058.00$ \\
\hline Productivity & t ha-1 & 42.75 & 31.49 \\
\hline Previewed batches per year & batches year-1 & 14 & 10 \\
\hline Production of charcoal per batch & t batch ${ }^{-1}$ & 27.12 & 26.06 \\
\hline Charcoal production per year & t year-1 & 379.68 & 260.00 \\
\hline Loss with the friability of charcoal (fines) & $\% /$ year & 8.38 & 9.68 \\
\hline Charcoal production per year (final) & $t_{\text {year }}^{-1}$ & 347.86 & 235.37 \\
\hline
\end{tabular}


batches year ${ }^{-1}$ for the annual wood volume of the 1st cycle of projects $A$ and $B$. With the volume of the coppicing (2nd cycle) it is possible to make 10 batches per year. In view of the production of charcoal by batch of 27.12 tons and the loss of friability with fines, there was a production of charcoal of 347.86 tons year ${ }^{-1}$ for the 1 st and 2 nd cycles of project $A$ and 1st cycle of project $B$, and 235.37 tons year ${ }^{-1}$ for the 2 nd cycle of project $B$ (Table 4 ).

\section{Economic viability analysis}

Table 5 shows the economic results obtained from the discounted cash flow analysis. It is observed that both projects obtained an IRR higher than the discount rate, and positive NPV, demonstrating the economic viability of both.

Comparatively, although the NPV of the replanting system was higher in all discount rate scenarios, the coppicing system obtained a higher IRR and lower payback than replanting, which demonstrates its greater viability and shorter term for reimbursement of the investment, even if the difference was small.

Although the economic results are very close, considering the IRR and Payback, the project of the coppicing system can be considered more viable. In other words, even if starting from lower forest productivity, and consequently, lower production of charcoal, its revenue still managed to pay the total costs, the financing and still generate profit. Its greater viability also occurred due to the fact that its costs per hectare are lower, since fewer interventions are required in this silvicultural system. With reduced implementation costs, compared to replanting, coppicing can bring greater financial flexibility to the forest producer who has less resources.

It is important to note that the two projects obtained positive net profit from the seventh year, that is, from the first

Table 5. Results of the economic analysis on a 21-year planning horizon.

\begin{tabular}{lccc}
\multicolumn{1}{c}{ Data } & Unit & Replanting & Coppicing \\
\hline NPV (8.0\%) & R\$ thousand & 407.96 & 375.60 \\
NPV (10.0\%) & R\$ thousand & 304.93 & 285.99 \\
NPV (12.0\%) & R\$ thousand & 228.73 & 218.55 \\
IRR & $\%$ & 35.6 & 37.5 \\
Payback & Years & 8 & 7 \\
\hline
\end{tabular}

carbonization. This shows that the revenue from the sale of charcoal has been robust in all years and has managed to pay for the costs of the projects.

For the sensitivity analysis of scenarios, two variables of significant sensitivity to economic results were identified: the sale price of charcoal and the productivity of wood.

The tables below show the sensitivity of the NPV (in R\$ thousand) for each project in relation to changes in the sale price of charcoal $\left(R \$ t^{-1}\right)$ and in wood productivity $\left(\mathrm{m}^{3} \mathrm{ha}^{-1}\right.$ year $^{-1}$ ).

Table 6 shows that the NPV of the replanting system is positive in all scenarios, even with price and productivity below that considered in this work, taking as a base scenario the productivity of $34.60 \mathrm{~m}^{3} \mathrm{ha}^{-1}$ year ${ }^{-1}$ and the price of $\mathrm{R} \$$ $600.00 \mathrm{t}^{-1}$.

As seen for the replanting project, in the coppice scenario (Table 7), positive results are observed in all variations in the price of charcoal and wood productivity, based on the productivity of $26.88 \mathrm{~m}^{3}$ ha $^{-1}$ year-1 and sales price of $\mathrm{R} \$$ $600.00 \mathrm{t}^{-1}$.

When comparing the two systems in these sensitivity scenarios, the following is observed: i) in the scenarios of lower productivity and reduced sales price of charcoal (less than or equal to $\mathrm{R} \$ \mathbf{4 5 0 . 0 0}$ per ton), the coppicing system obtained highest NPV; ii) this means that this system is less vulnerable to fluctuations in these variables than the replanting, which requires more investments for its implementation; iii) this type of analysis is essential for the producer to visualize the risks of his investment in the face of technical changes, such as productivity, and of the market, such as the selling price of charcoal.

Therefore, after evaluating the technical and economic results, this work considers the following: if the producer takes into account only the quality of wood and charcoal, the option for replanting would be more interesting, since the producer will be able to deliver a final product with better quality for the consumer.

If the producer decides on a system with less relative risk in the face of market fluctuations, the coppicing system may be more interesting, due to its lower financial expenditure and satisfactory economic results, even in adverse scenarios, such as the reduced price of charcoal and lower productivity.

Table 6. NPV sensitivity analysis (10.00\%) of the replanting project.

\begin{tabular}{|c|c|c|c|c|c|c|c|c|c|c|}
\hline \multirow{2}{*}{$\begin{array}{c}\text { NPV } \\
\text { (R\$ thousand) }\end{array}$} & & \multicolumn{9}{|c|}{ Productivity ( $\mathrm{m}^{3} \mathrm{ha}^{-1}$ year $^{-1}$ ) } \\
\hline & & 26.60 & 28.60 & 30.60 & 32.60 & 34.60 & 36.60 & 38.60 & 40.60 & 42.60 \\
\hline \multirow{7}{*}{$\begin{array}{c}\text { Charcoal price } \\
\qquad\left(R \$ t^{-1}\right)\end{array}$} & 400.00 & 3.69 & 23.02 & 39.82 & 54.56 & 67.60 & 79.21 & 89.62 & 99.01 & 107.51 \\
\hline & 450.00 & 63.02 & 82.35 & 99.16 & 113.90 & 126.93 & 138.55 & 148.96 & 158.34 & 166.84 \\
\hline & 500.00 & 122.36 & 141.69 & 158.49 & 173.23 & 186.27 & 197.88 & 208.29 & 217.67 & 226.18 \\
\hline & 550.00 & 181.69 & 201.02 & 217.82 & 232.56 & 245.60 & 257.21 & 267.62 & 277.01 & 285.51 \\
\hline & 600.00 & 241.02 & 260.35 & 277.16 & 291.90 & 304.93 & 316.55 & 326.96 & 336.34 & 344.84 \\
\hline & 750.00 & 419.02 & 438.35 & 455.16 & 469.90 & 482.94 & 494.55 & 504.96 & 514.34 & 522.84 \\
\hline & 800.00 & 478.36 & 497.69 & 514.49 & 529.23 & 542.27 & 553.88 & 564.29 & 573.67 & 582.18 \\
\hline
\end{tabular}


Table 7. NPV sensitivity analysis (10.00\%) of coppicing project.

\begin{tabular}{|c|c|c|c|c|c|c|c|c|c|c|}
\hline \multirow{2}{*}{$\begin{array}{c}\mathrm{NPV} \\
\text { (R\$ thousand) }\end{array}$} & & \multicolumn{9}{|c|}{ Productivity $\left(\mathrm{m}^{3} \mathrm{ha}^{-1}\right.$ year $\left.{ }^{-1}\right)$} \\
\hline & & 18.88 & 20.88 & 22.88 & 24.88 & 26.88 & 28.88 & 30.88 & 32.88 & 34.88 \\
\hline \multirow{9}{*}{$\begin{array}{c}\text { Charcoal price } \\
\left(\mathrm{R} \$ \mathrm{t}^{-1}\right)\end{array}$} & 400.00 & 55.96 & 54.48 & 61.21 & 67.95 & 74.69 & 81.42 & 79.94 & 86.68 & 93.42 \\
\hline & 450.00 & 104.70 & 103.22 & 111.32 & 119.42 & 127.51 & 135.61 & 134.13 & 142.23 & 150.33 \\
\hline & 500.00 & 153.44 & 151.96 & 161.42 & 170.88 & 180.34 & 189.80 & 188.32 & 197.78 & 207.24 \\
\hline & 550.00 & 202.19 & 200.70 & 211.53 & 222.35 & 233.17 & 243.99 & 242.51 & 253.33 & 264.15 \\
\hline & 600.00 & 250.93 & 249.45 & 261.63 & 273.81 & 285.99 & 298.18 & 296.69 & 308.88 & 321.06 \\
\hline & 650.00 & 299.67 & 298.19 & 311.73 & 325.28 & 338.82 & 352.37 & 350.88 & 364.43 & 377.97 \\
\hline & 700.00 & 348.41 & 346.93 & 361.84 & 376.74 & 391.65 & 406.55 & 405.07 & 419.98 & 434.88 \\
\hline & 750.00 & 397.16 & 395.67 & 411.94 & 428.21 & 444.48 & 460.74 & 459.26 & 475.53 & 491.79 \\
\hline & 800.00 & 445.90 & 444.42 & 462.04 & 479.67 & 497.30 & 514.93 & 513.45 & 531.08 & 548.71 \\
\hline
\end{tabular}

\section{Conclusion}

The wood from the silvicultural system of coppicing has a higher heartwood/sapwood ratio, which resulted in a charcoal of greater friability, when compared to the replanting system. In addition, wood from coppicing showed a lower mean annual increment, which directly impacted its productivity in charcoal.

The replanting and coppicing systems were economically viable, with IRRs higher than the discount rate and positive NPV. In the comparison between the two, the coppicing system obtained slightly better economic results, with lower payback, that is, shorter term for reimbursement of the investment and higher IRR. Thus, even with lower productivity and quality of wood, which negatively impacts the charcoal produced, this system has led to more satisfactory economic results, in addition to being less vulnerable in situations of low charcoal prices. Therefore, this system becomes an interesting option economically for the forest and charcoal producer.

\section{Literature Cited}

Alvares, C.A.; Stape, J.L.; Sentelhas, P.C.; Gonçalves, J.L. M.; Sparovek, G. Köppen's climate classification map for Brazil. Meteorologische Zeitschrift, v. 22, n. 6, p. 711-728, 2013. https:// doi.org/10.1127/0941-2948/2013/0507.

Associação Brasileira de Normas Técnicas - ABNT. NBR 11941: Madeira: determinação da densidade básica. Rio de Janeiro: ABNT, 2003. 6 p.

Associação Brasileira de Normas Técnicas - ABNT. NBR 8112: Carvão vegetal: análise imediata. Rio de Janeiro: ABNT, 1986. 8p.

Associação Brasileira de Normas Técnicas - ABNT. NBR 8633: Carvão vegetal: determinação do poder calorífico. Rio de Janeiro: ABNT, 1984. $13 \mathrm{p}$.

Cacau, F.V.; Reis, G.G.; Reis, M.G.F.; Leite, H.G.; Alves, F.F.; Souza, F.C. Decepa de plantas jovens de eucalipto e manejo de brotações, em um sistema agroflorestal. Pesquisa Agropecuária Brasileira, v.43, n.11, p.1457-1465, 2008. https://doi.org/10.1590/S0100204X2008001100003.

Cardoso, M.T. Desempenho de um sistema de forno-fornalha para a combustão de gases na carbonização da madeira. Viçosa: Universidade Federal de Viçosa, 2010. 89p. Masters Dissertation. http://locus.ufv.br/handle/123456789/3033. 19 Mar. 2020.
Carneiro, A.C.O.; Vital, B.R.; Frederico, P.G.U.; Fialho, L.F.; Figueiró, C.G.; Silva, C.M.S. Caracterização energética das madeiras de clones de Eucalyptus cultivados em diferentes localidades. Ciência da Madeira, v.8, n.3, p.127-135, 2017. https://doi. org/10.12953/2177-6830/rcm.v8n3p127-135.

Carneiro, A.C.O.; Vital, B.R.; Oliveira, A.C.; Pereira, B.L.C.; Pirólise lenta da madeira para produção de carvão vegetal. In: Santos F., Colodete J.; Queiroz J.H. (Eds.). Bioenergia e biorrefinaria: cana de açúcar e espécies florestais. 1.ed. Viçosa: Os Editores; 2013. p.429-457.

Chen, Z.; Hu, M.; Zhu, X.; Guo, D.; Liu, S.; Hu, Z.; Xiao, B.; Wang, J., Laghari, M. Characteristics and kinetic study on pyrolysis of five lignocellulosic biomass via thermogravimetric analysis. Bioresource Technology, v.192, p.441-450, 2015. https://doi. org/10.1016/j.biortech.2015.05.062.

Cherelli, S. G. Cerne e alburno em eucaliptos: influência da espécie e da idade nas propriedades tecnológicas. Botucatu: Universidade Estadual Paulista "Júlio de Mesquita Filho"; Faculdade de Ciências Agronômicas de Botucatu, 2015. 165p. Masters Dissertation. http://hdl.handle.net/11449/123247. 03 Mar. 2020.

Costa, C. S.; Leal, C. S.; Santos, L. C.; Carvalho, A. M. L.; Oliveira, A. C.; Pereira, B. L. C. Propriedades da madeira de cerne e alburno de Eucalyptus camaldulensis. Ciência da Madeira, v.8, n.1, p.10-20, 2017. https://doi.org/10.12953/2177-6830/rcm.v8n1p10-20.

Empresa de Assistência Técnica e Extensão Rural do Estado de Minas Gerais - Emater. Valores de terra nua 2019. Belo Horizonte: Emater, 2019. 23p. http://www.emater.mg.gov.br/doc/site/ Valor\%20Terra\%20Nua/VALORES\%20DE\%20TERRA\%20NUA\%20 2019.pdf. 19 Mar. 2020.

Figueiredo, M.E.O.; Longue, D.; Pereira, A.K.S.; Carneiro, A.C.O.; da Silva, C.M.S. Potencial da madeira de Pterogyne nitens Tul. (madeira-nova) para produção de carvão vegetal. Ciência Florestal, v.28, n.1, p.420-431, 2018. https://doi. org/10.5902/1980509831620.

Figueiró, C.G.; Carneiro, A.C.O.; Fialho, L.F.; da Silva, C.S.; Peres, L.C. Energetic valorization of sawmill waste through slow pyrolysis. Revista Floresta, v.49, n.1, p.109-116, 2019. https://doi. org/10.5380/rf.v49i1.57647.

Frederico, P.G.U. Efeito da região e da madeira de eucalipto nas propriedades do carvão. Viçosa: Universidade Federal de Viçosa, 2009. 73p. Masters Dissertation. http://locus.ufv.br/ handle/123456789/3024. 19 Mar. 2020.

Goldschmid, O. Ultraviolet spectra. In: Sarkanen, K.V.; Ludwig, C.H. (Eds.). Lignins: occurrence, formation, structure and reactions. New York: Wiley Interscience, 1971. p.241-266. 
Gomide J. L.; Demuner B. J. Determinação do teor de lignina em material lenhoso: método Klason modificado. O Papel, v.47, p. 36-38, 1986. https://www.researchgate.net/publication/284128446. 22 Mar. 2020.

Gonçalves, J.L.M.; Rocha, J.H.T.; Bazani, J.H.; Hakamada, R. E. Nutrição e adubação da cultura do eucalipto manejada no sistema de talhadia. In: Prado, R.M.; Wadt, P.G.S. (Eds.). Nutrição e adubação de espécies florestais e palmeiras, Jaboticabal: FCAV; CAPES, 2014. p.349-382.

Haykiri-Acma, H.; Yaman, S.; Kucukbayrak, S. Comparison of the thermal reactivities of isolated lignin and holocellulose during pyrolysis. Fuel Processing Technology, v.91, n.7, p.759-764, 2010. https://doi.org/10.1016/j.fuproc.2010.02.009.

Henriques, E.P. Variabilidade genética em progênies de Eucalyptus urophylla S. T. Blake para carvão vegetal. Botucatu: Universidade Estadual Paulista "Júlio de Mesquita Filho" Faculdade de Ciências Agronômicas de Botucatu, 2012. 126p. Masters Dissertation. http://hdl.handle.net/11449/99783. 19 Mar. 2020.

Imaña, C.R.; de Souza, A.N.; Ângelo, H.; da Silva, M.L.; Rezende, J.L.P. A tributação na produção de carvão vegetal. Cerne, v.2, n.1, p.916, 2015. https://doi.org/10.1590/01047760201521011456.

Indústria Brasileira de Árvores - IBÁ. Relatório 2019: ano base 2018. São Paulo: IBÁ, 2018. 80p. https://iba.org/datafiles/publicacoes/ relatorios/iba-relatorioanual2019.pdf. 23 Mar. 2020.

Kumar, A.; Dhillon, G.P.S. Variation of sapwood and heartwood content in half-sib progenies of Eucalyptus tereticornis Sm. Indian Journal of Natural Products and Resources, v.5, n.4, p.338-344, 2014. http:// nopr.niscair.res.in/handle/123456789/30556. 03 Mar. 2020.

Martelanc, R.; Passin, R.; Pereira, F. Avaliação das empresas: um guia para fusões \& aquisições e privaty. São Paulo: Pearson Prentice Hall, 2010. 320p.

Mohan, D.; Pittam, C.U; Stelle, P.H. Pyrolysis of wood/biomass for bio-oil: a critical review. Energy and Fuels, v.20, n.3, p.848-889, 2006. https://doi.org/10.1021/ef0502397.

Oliveira, A.C.; Salles, T.T.; Pereira, B.L.C.; Carneiro, A.C.O.; Braga, C.S.; Santos, R.C. Viabilidade econômica da produção de carvão vegetal em dois sistemas produtivos. Floresta, v.44, n.1, p.143152, 2014. https://doi.org/10.5380/rf.v44i1.32043.

Pereira, B.L.C.; Carneiro, A.C.O.; Carvalho, A.M.M.L.; Colodette, J.L.; Oliveira, A.C.; Fontes, M.P.F. Influence of chemical composition of Eucalyptus wood on gravimetric yield and charcoal properties. BioResources, v.8, n.3, p. 4574-4592, 2013. https://doi. org/10.15376/biores.8.3.4574-4592.

Pulrolnik, K.; de Barros, N.F.; Silva, I.R.; Novais, R.F.; Brandani, C.B. Estoques de carbono e nitrogênio em frações lábeis e estáveis da matéria orgânica de solos sob eucalipto, pastagem e cerrado no Vale do Jequitinhonha MG. Revista Brasileira de Ciência do Solo, v.33, n.5, p.1125-1136, 2009. https://doi.org/10.1590/S0100-06832009000500006.
R Core Team. R. A language and environment for statistical computing. Vienna: R Foundation for Statistical Computing, 2018.

Ribeiro, G.B.D; Carneiro, A.C.O.; Lana, A.Q.; Valverde, S.R. Economic viability of four charcoal productive systems from Minas Gerais state. Revista Árvore, v.44, e4401, 2020. https://doi. org/10.1590/1806-908820200000001.

Ribeiro, G.B.D; Isbaex, S.; Valverde, S.R. A quantitative analysis of forestry sector contribution for the increase of Minas Gerais municipalities revenues. Revista Árvore, v.42, n.3, e420303, 2018. https://doi.org/10.1590/1806-90882018000300003.

Ribeiro, M.D.S.B.; Jorge, L.B.; Mischan, M.M.; dos Santos, A. L.; Ballarin, A.W. Avaliação da produção de biomassa do fuste de um clone híbrido de eucalipto sob diferentes espaçamentos. Ciência Florestal, v.27, n.1, p.31-45, 2017. https:// doi.org/10.5902/1980509826445.

Silva, M.L.; Rezende, J.L.P.; Lima, V.B.; Cordeiro, S.A.; Coelho, L.M. Métodos de cálculo do custo da terra. Cerne, v. 4, n. 1, p.7581, 2008. http://cerne.ufla.br/site/index.php/CERNE/article/ download/337/282. 20 Jun. 2020.

Silva, M.L.; Ribeiro, C.A.S.; Estabelecimento de rotação econômica para uma floresta regulada. Revista Árvore, v. 30, n. 1, p. 65-73, 2006. https://doi.org/10.1590/S0100-67622006000100009.

Stape, J.L.; Binkley, D.; Ryan, M.G.; Fonseca, S.; Loos, R.A.; Takahashi, E.N.; Silva, C. R.; Silva, S.R.; Hakamada, R.E.; Ferreira, J.M.D.A.; Lima, A.M.N.; Gava, J.L.; Leite, F.P.; Andrade, H.B.; Alves, J.M.; Silva, G.G.C.; Azevedo, M.R. The Brazil Eucalyptus potential productivity project: influence of water, nutrients and stand uniformity on wood production. Forest Ecology Management, v. 259, n.9, p.1684-1694, 2010. https://doi.org/10.1016/j. foreco.2010.01.012.

Technical Association of the Pulp and Paper Industry - TAPPI. TAPPI test methods T 204 om-88: solvent extractives of wood and pulp. In: TAPPI (Ed.). TAPPI standard method. Atlanta: TAPPI, 2001.

Trugilho, P.F.; Lima, R.A.B.; de Assis, M.R.; Simetti, R.; Loureiro, B.A. Variação radial e longitudinal do rendimento gravimétrico de carvão vegetal em clone de eucalipto/Radial and longitudinal variation of the gravimetric yield of charcoal in Eucalyptus clone. Brazilian Journal of Development, v. 5, n. 3, p. 25352541, 2019. http://www.brjd.com.br/index.php/BRJD/article/ view/1319/1194. 23 Mar. 2020.

Ucar, S.; Ozkan, A.R. Characterization of products from the pyrolysis of rapeseed oil cake. Bioresource Technology, v.99, n.18, p.877718776, 2008. https://doi.org/10.1016/j.biortech.2008.04.040.

Xavier, A.; Wendling, I.; Silva, R.L. Silvicultura clonal - princípios e técnicas. 2.ed. Viçosa: Editora UFV, 2009. 272p. 